\title{
Same-Sex Marriage versus Human Rights: The Legality of the "Anti Gay \& Lesbian Law" in Nigeria
}

\author{
Magaji Chiroma ${ }^{1,2}$ \& Awwal Ilyasu Magashi ${ }^{3}$ \\ ${ }^{1}$ Department of Shari'ah Law, Faculty of Law, University of Maiduguri, Nigeria \\ ${ }^{2}$ Ahmad Ibrahim Kulliyah of Laws, International Islamic University Malaysia, Malaysia \\ ${ }^{3}$ Faculty of Law, Bayero University, Kano, Nigeria \\ Correspondence: Magaji Chiroma, Ahmad Ibrahim Kulliyah of Laws, International Islamic University Malaysia, \\ Malaysia. Tel: 60-16-699-5871. E-mail: magajichiroma@gmail.com
}

Received: December 5, 2014 Accepted: December 18, 2014 Online Published: May 22, 2015

doi:10.5539/ilr.v4n1p11 URL: http://dx.doi.org/10.5539/ilr.v4n1p11

\begin{abstract}
As an avenue to guarantee and ensure the enjoyment of right to freedom of private and family life, spouses have been permitted and encouraged by various laws to get married to one another. The concept of marriage has been generally understood and confined within the following meaning: "a legal union between a male and a female with a view to becoming husband and wife." Such definition precludes any unionism that may occur between same-sex couples in a manner contrary to the law and public policy. In the recent past, the Government of Nigeria has signed into law a bill known as "Same-Sex Marriage (Prohibition) Bill, 2011". The Bill prohibits a marriage between two same couples and all sort of matters connected therewith such as forming a union that has to do with same-sex marriage. The prohibition has been supported by the religious declarations, people's culture, public policy and morals in the country. The passage of the Bill into law has attracted series of condemnations by some of the international community and the proponents of same-sex marriage. For it is said to have been enacted contrary to the human rights law and the Nigerian constitution. According to the proponents of same-sex marriage, the passage of the Bill into law is an attempt to deprive some minorities of their basic social rights such as right to freedom of private and family life; freedom to assemble peacefully; and freedom from discrimination as contained under the International, regional and domestic instruments. Hence according to them, the Enactment is illegal and unconstitutional. Hence, it is against this controversy that the paper attempts to examine the legality of the anti- gay law in Nigeria with a view to drawing a line of demarcation between the protection of human rights on one part and the right of gays to marry one another on the other part.
\end{abstract}

Keywords: same-sex marriage, human right, anti-gay \& lesbian law, legality, Nigeria

\section{Introduction}

Time before now, marriage has been understood as a union between a male and a female adult with a view to becoming husband and wife. Most of the societal values, norms and cultures in the world have conventionally affirmed that the institution of marriage between two different sexes is the only mechanism within which a sexual desire and human procreation can be attained. To this end, various legal regimes in the world have built upon such values and promulgated some laws which regulate the relationship and unionism between married couples. Notwithstanding the promulgation of various legislation on the conduct and regulations of marriage in the society, there are still some challenges bedeviling the institution of marriage. One of such challenges is the misconception about what the concept of marriage per se is all about. The definition of marriage has been appeared to be a controversial issue nowadays, more especially with the growing trend of new concepts of marriage in the world. The trend has paved a way for agitation to redefine the term "marriage" to include same-sex marriage and in order to justify homosexuality and lesbianism. The concept of same-sex marriage is equally a growing trend in Nigeria, which is largely believed by many Nigerians as something that is contrary to

\footnotetext{
* This is a version of the paper presented at the 2nd World Conference on Islamic Thought \& Civilization: Rise and Fall of Civilization Contemporary States of Muslim Affairs (WCIT 2014), 18 - 19 August, 2014, held at Casuarina Hotel @ Meru, Ipoh Perak, Malaysia. The Conference was organized by Kolej Universiti Islam Sultan Azlan Shah (Sultan Azlan Shah Islamic University College), Ipoh- Perak, Malaysia
} 
human norms, values and public policy. Thus, the Federal Government of Nigeria criminalized it hence by making it punishable offence under the law. This position has been criticized by some of the international community, for its violation of the principles of human rights agreed upon under the UN Charter and Universal Declaration of Human Rights (UDHR); Regional Human Rights instruments; and the States constitutions. Among the human rights said to have been violated include: the right to freedom of private and family life; right to freedom of peaceful assembly and association; right to freedom of conscience, thought and religion; and right to freedom from discrimination. It is based on these issues that the paper examines the legality of same-sex marriage law in Nigeria, thereby juxtaposing the notion of same-sex marriage from the concept of human rights.

\section{The Concept of Marriage \& Same-Sex Marriage}

To begin with, In English, the word "marriage" was said to have been originated from the old French term known as marier 'marry', which according to the Oxford English Dictionary is the legally or formally recognized union of a man and a woman as partners in a relationship. ${ }^{1}$ The Dictionary has attempted to redefine marriage in order to accommodate the concept of same-sex marriage, but yet it has not been fully materialized. Still at the moment, the term marriage has been considered as a formal union between male and a female with a view to becoming husband and wife. However, the Dictionary, in an attempt to redefine the term marriage, has made small annotation which aimed at co-opting the concept of same-sex marriage. Thus, the annotation reads: "(in some jurisdictions) marriage can be defined as a union between partners of the same sex". ${ }^{2}$ Notwithstanding the annotation, the activists and proponents of same-sex marriage have not been satisfied with the definition, they have lamented that the annotation per se is discriminatory in nature; and that, why shouldn't it be co-opted and captioned in the primary text? $?^{3}$ Therefore, such a re-definition still remains unsatisfactory to them despite the distinctive nature of the Oxford English Dictionary among other dictionaries in terms of its historical record and quality of language. ${ }^{4}$ The controversy that has been involved in the definition of marriage has equally impacted on the passage of same-sex marriage law in UK. Notwithstanding the fact that the definition of marriage in UK has already been changed even before the passage of the same-sex marriage law in the country. However, during the Parliamentary debates prior to the passage of the Bill, most members of the Parliaments who were against the Same-Sex Marriage Act had largely expressed their deep concerns over the redefinition of the word "marriage". In fact, this also indicates how controversial the matter has been even among the European countries, and of course, the level of which the trend is gaining a ground day- in- day out in such jurisdictions. ${ }^{5}$

In another European version of the definition, the concept marriage should not strictly be construed as a union between a male and a female, but also a union between same-sex persons. Thus, the French Dictionary, "Larousse" has defined marriage as a solemn union between two persons who have same or different sex. ${ }^{6}$ Most of these definitions do not consider the "person's sex" as a factor. To this effect, some definitions of marriage did not in toto contain or provide anything related to gender. In line with the above, the Canada Space Dictionary describes marriage as "the state of being a married couple voluntarily joined for life (or until divorce)". This implies that a marriage can be a union between couples regardless of their sex. It could be between two male; or two female; or male and female. In fact, the above definition reiterates the legality of same-sex marriage in some jurisdictions such Canada. $^{7}$

The term marriage from the Islamic perspective was originated from the Arabic word of "nikah", that is to say, to collect things together. ${ }^{8}$ Arabs use the word nikah in expressing some activities surrounding their daily lives. For instance, if they want to describe a penetration of rainfall into soil, they say nakaha al-matru al-ard. Similarly,

\footnotetext{
1 Oxford Dictionaries Language Matters, available at http://www.oxforddictionaries.com/definition/english/marriage, accessed on $14 / 06 / 2014$

2 Pink News, Oxford Dictionary will change the Definition of 'Mariage' to include equal marriage, available at http://www.pinknews.co.uk/2013/07/25/oxford-dictionary-will-change-the-definition-of-marriage-to-include-equal-marriage/, accessed on $14 / 06 / 2014$

${ }^{3}$ Ibid

${ }^{4}$ Ibid

${ }^{5}$ Ibid

${ }^{6}$ Ibid

7 Pink News, Oxford Dictionary will change the Definition of 'Mariage' to include equal marriage, available at http://www.pinknews.co.uk/2013/07/25/oxford-dictionary-will-change-the-definition-of-marriage-to-include-equal-marriage/, accessed on $14 / 06 / 2014$

8 Shahzad Iqbal Sham, Some aspects of Marriage and Divorce in Muslim Family Law, at 10-12 < http://www.pu.edu.pk/szic/journal/cu...20Divorce).pdf>, viewed on 09/06/2014
} 
when trees are intermingled in the junggle, they say tanakahat al- ashjar. ${ }^{9}$ The word nikah therefore is used literally to mean the absorbing of a thing into another different thing as cited in the above examples. However, the word nikah technically refers to cohabitation (mubasharat) which becomes legitimate only after a valid contract between a man and a woman. ${ }^{10}$ A contract here can be referred to as a knot or a tie. As a woman and a man are tied together by a knot (of wedding called the wedlock), hence nikah is called aqd (a marriage contract) between man and a woman with view to becoming husband and wife. ${ }^{11}$ Therefore from the Islamic perspective, marriage can be defined as a lawful union between a male and a female in accordance with the formal way prescribed by Shari'ah. ${ }^{12}$ One of the objectives of marriage in Islam is that, it gives love a chance to play among the real and natural lovers (i.e. male and a female) so that their morals would be protected or safeguarded. ${ }^{13}$ To this end, the Almighty Allah says: "It is He Who created you from a single person, and made his mate of like nature (human being), in order that he might dwell with her (in love)."14 Similarly, the Prophet (s.a.w.) was reported to have said: "O Young people Whoever of you can afford marriage, let him get married, for marriage helps restrain the looks and preserve their chastity, He who cannot afford it, let him observe fasting, for fasting is a deterrent." 15 This implies that sexual relationship has been known only between a male and a female creature; hence it is a natural phenomenon. Thus, marriage in Islam has been understood as an acceptable means of sexual satisfaction.

In the Nigerian Matrimonial Causes Act, the term "marriage" has not been defined based on the moral and religious ground. ${ }^{16}$ However, it has been understood from its context to mean a legal union between male and female with a view among other things to giving birth to children. This definition though is not from the explicit provision of the Act, but has been inferred from the definition of phrase "children of the marriage" as per the provision of the Act. The provision reads: "... any child of the husband and wife born before the marriage, whether legitimated by the marriage or not..."17 the word "born" used in the provision implies and supports the concept of marriage as a union between a man and a woman with a view to giving birth to children. As it is a well established fact that same-sex couple shall never give birth to a biological child. ${ }^{18}$ Similarly, the Act in providing the impediments of marriage under its schedule, ${ }^{19}$ has only recognizes the marriage between a man and a woman with the exclusion or prohibition of certain degree of persons who are affected by either consanguinity (blood relation) or affinity (the existing marital relation with any of a spouse blood relative). This may includes the parents of the spouses (how-so-ever-high); the descendants of the spouses (how-so-ever-low); and the spouses blood brothers and sisters in- law (how-so-ever- remote) ${ }^{20}$ The provision under this schedule implies that marriage is a union between male and female persons; hence anything contrary to this is not allowed and should not be considered as marriage. In fact, the opening paragraphs of the Act schedule affirms to the effect that "Marriage of a man is prohibited if the woman is..." and "Marriage of a woman is prohibited if the man is..."21 Hence, this is a sufficient authority to conclude that the Matrimonial Causes Act in Nigeria does not recognise any marriage other than the marriage between a man and a woman. Although this is an inference that has been drawn from the provisions of the law, but it is indeed logical for any legislation or statute to be inferred if circumstances so demand as in this case. However, in any case, there should be a need to have a

\footnotetext{
${ }^{9}$ Ibid

${ }^{10}$ Ibid

${ }^{11}$ Ibid

12 See Iqbal Sham Shahzad, "Some aspect of Marriage and Divorce in Muslim Family Law", Pp 10-22, available at http://pu.edu.pk/images/journal/szic/currentissue pdf/E-, accessed on 27/12/2013

${ }^{13}$ Mahmoud M Istimblli and Abdelhamid Eliwa, The Brides' Boon- Tuhfat Al-A'rous, p 14, available at http://www.islambasics.com, accessed on 27/12 2013

${ }^{14}$ Qur'an, AI-A 'raf: 189

${ }^{15}$ Muhammad Ibn Isma'il, Sahih Al Bukhari, Kitab an Nikah Book 7, Volume 62, Hadith No. 3 \& 4

${ }^{16}$ Marriage under the Matrimonial Causes Act includes a purported marriage that is void, but does not include one entered into according to Muslim rites or other customary law. See the Matrimonial Causes Act,No. 18 of 1970

${ }^{17}$ Section 69 (b) of the Matrimonial Causes Act, No. 18, of 1970

${ }^{18}$ It is a scientific proof that a woman can only give birth to a child after the following processes: impregnation by a man; ejaculation of the man's and woman's sperm; and fertilization of the man's sperm inside the woman's ovum. See a Brief overview of Male and Female Reproductive System, available

https://www.boundless.com/microbiology/diseases/microbial-genitourinary-system-diseases/brief-overview-male-and-female-reproductivesy stem-1/, accessed on $24 / 06 / 2014$

${ }^{19}$ First Schedule section 69 of the Matrimonial Causes Act, No. 18, 1970

${ }^{20}$ Ibid

${ }^{21}$ Ibid
} 
comprehensive definition of marriage in the Marriage Act or Matrimonial Causes Act. To this effect, the Government in Nigeria as well as some NGOs have been for long pushing forward to see that the term "Marriage" under both the Marriage Act and Matrimonial Causes Act has been explicitly defined. Thus, it has been proposed sometimes in a working paper on the Reform of the laws of marriage in Nigeria (2006), that the definition of marriage should contain the following words: “...a union intended for life between a male person and a female person to the exclusion of all others during the continuance of the marriage, and for the avoidance of doubt, shall not apply with respect to the contracting marriage under Customary Law or Islamic Law."22 The term "Marriage" therefore, can be defined as a legally binding union between a man and a woman be it performed under the authority of the State, Islamic Law or Customary Law. ${ }^{23}$

The notion of same-sex marriage in recent times is one of the recurrent controversial issues in the world, more especially with the criminalization of the issue by some countries. The phrase "Same-Sex Marriage" can be defined as a civil union between two same couples with a view to cohabiting as husband and wife. ${ }^{24}$ In Nigeria, the controversy over homosexuality and same-sex marriage has raised an alarm when the Same-Sex Marriage (Prohibition) Bill 2011 was finally passed into law by the Nigerian Authority in January 2014. This has continued to draw the attention of many people within and outside the country as to its legality. Thus, some proponents and activists of same-sex marriage began to condemn the act of the Nigerian Authority. Hence according to them, the passage of the Act has infringed over the rights of so-called minority (Lesbians, Gays, Bisexuals and Transgender LGBT) in the country, and for that reason, the Act is in violation of the International Human Rights law ratified and domesticated in the country's constitution. The activists maintained that the purported act of the Nigerian Government tantamount to deprivation of so many rights; ranging from right to freedom of thought and conscience, ${ }^{25}$ freedom from discrimination, ${ }^{26}$ right to freedom of private and family life, ${ }^{27}$ as well as freedom of association and peaceful assembly ${ }^{28}$ as enshrined in the Nigerian constitution 1999. Although not all people share the same views, however some advocates of same-sex marriage attributed the blame regarding the prohibition of same-sex marriage on the Nigerian colonial masters who have, at the time of departing also criminalized the marriage thereby making some provisions in the penal laws to that effect. They hold that the current anti-gay law in Nigeria has been influenced by the colonial laws that were inherited from the colonial masters who according to the activists, have now shifted a ground from their former position of criminalizing same-sex marriage to the new position of legalizing it, which they now described it as advancement and development. Similarly, some advocates also hold the view that the prohibition of same-sex marriage has been influenced by the Shari'ah legal system, which is applicable to the Northern part of the country. ${ }^{29}$ Perhaps, the latter opinion may be correct, but it is doubtful if the former opinion could stand, relying on the history that, Islam predates the colonial administration in Nigeria, and that, Islam has equally prohibit same-sex marriage even before the advent of the colonial administration. Why then attributing the blame on the colonial administration, as if law and morality did not exist in Nigeria until the arrival of the colonial administrators in the country. Therefore, it is our humble submission that the prohibition of same-sex marriage in Nigeria could not be detached from the influence of religions and culture, which forms the integral aspect of people's lives in the country. It is a notorious fact that Islamic law applies in the Northern part of the country

\footnotetext{
${ }^{22}$ Nigerian Law Reform Commission, the working paper on the Reform of the laws of marriage in Nigeria, Volume II, 2006, Abuja, Nigeria, at 20

${ }^{23}$ See section 7 and section 2 (the interpretation section) of the SSMPA

${ }^{24}$ See section 2 (Interpretation section) of the Bill for an Act to make provisions for the prohibition of sexual relationship between persons of the same-sex, celebration of marriage by them and for other matters connected therewith

${ }^{25}$ Section 38 of the Constitution of the Federal Republic of Nigeria (1999) as amended, the section provides: "Every person is entitled to freedom of thought conscience and religion..."

${ }^{26}$ Section 42 of the Constitution of the Federal Republic of Nigeria (1999) as amended, the section provides: "A citizen of Nigeria of a particular community, ethnic group, place of origin, sex, religion or political opinion, shall not, by reason only that he is such a person: (a) be subjected either expressly by, or in the practical application of, any law enforce in Nigeria or any executive or administrative action of the government, to disabilities or restriction to which citizen of Nigeria of other communities, ethnic groups, places of origin, sex, religions, or political opinions are not made subject."

${ }^{27}$ Section 37 of the Constitution of the Federal Republic of Nigeria (1999) as amended, the section provides: "the privacy of citizens, their homes, correspondence, telephone conversations and telegraphic communications is hereby guaranteed and protected."

${ }^{28}$ Section 40 of the Constitution of the Federal Republic of Nigeria (1999) as amended, the section provides: "Every person shall be entitled to assemble freely and associate with other persons, and in particular he may form or belong to any political party, trade union or any other association for the protection of his interest."

${ }^{29}$ Joseph Onuche, Same Sex Marriage in Nigeria: A Philosophical Analysis, International Journal of Humanities and Social Science Vol. 3 No. 12 [Special Issue - June 2013], 93-98
} 
even before the advent of the colonial administration; ${ }^{30}$ and in the Southern part of the country, it was the customary law that applies, ${ }^{31}$ and such customs have also frowned at the practice of same-sex marriage. ${ }^{32}$

The Islamic law prohibits homo-sexuality, and prescribed a punishment of death penalty (by way of stoning) against a convict, based on the fact that the Almighty Allah did same on the people of Lut (Lot) ${ }^{33}$ when they neglected his call to desist from sodomy. ${ }^{34}$ It is also based on this, that the act of sodomy in Islam has been considered as an impure act. The Prophet (s.a.w.) has declared that any person who commits sodomy is totally in a state of impurity, to the extent that even if he can take bath with all the water of this world, it could not purify him. He is indeed a cursed person in the side of Allah. ${ }^{35}$ Furthermore, sodomy was also considered as a grievous and abominable act in Islam, to the effect that the entire community (the then Palastine) was turned upside down by the Almighty Allah as a result of their disobedience to Allah (to stop committing sodomy). ${ }^{36}$ Thus, such people were therefore marked as wrongdoers (Zalimun) by the Almighty Allah. ${ }^{37}$ In a hadith, it was narrated that not only the principal actors but also a person who allows himself to be mounted from behind shall be equally liable for the act and shall both be dwelled in the extreme hell fire and abide therein eternally. ${ }^{38}$

In view of the nature of the Nigerian Nation, the Federal Government of Nigeria, in January 2014 took its pains to finally pass into law the Same-Sex Marriage (Prohibition) Bill 2011. As a result of the overwhelming support received by the general public in the country, the Bill was smoothly passed and endorsed by the appropriate authority. To this end, the Senate in an all-in-favour debate on the Bill, and took a strong stand to condemn it in toto. Thus, Senator Domingo Obende the sponsor of the Bill opened the debate by appealing to his colleagues to take an urgent precautions and measures against the growing trend of same-sex marriage which may lead to a breakdown of the Nigerian society, for it lacks both moral and religious justifications. ${ }^{39}$ Fortunately and interestingly, all the Senators that have debated on the Bill at the Senate plenary session accepted the Obende's line of argument. Among the distinguished senators that supported the passage of the Bill into law was Senator Oluremi Tinubu (a distinguished Senator from Lagos State), who submitted that the act of allowing persons of same-sex to marry one another is in toto contravenes the people morals, hence it is spiritually wrong and unacceptable in the country. The same position upheld by the Senate President, Senator David Mark, who has equally voiced out his support for the Bill, that no culture and people's tradition in the country will support it let alone the religions. ${ }^{40}$ However, the comment and position upheld by the Senate President did not go down well with the gay community in Nigeria. In their own counter argument presented by their spoke person, Dr. Otibho Obiowu at the Senate public hearing was that, so many Nigerians have left their homeland because of the fact that same-sex unions are not supported by the government. He further mentioned that by passing the Bill into law, the country has been tying itself down from ripping the fruits of its plants. That is to say, the experts and talented Nigerians in Diaspora who have chosen to be gays, lesbians, bisexuals and transsexuals will not be able to come down to their father land in order to contribute their own quota. According to him, the action may have negative impact on the country's development. ${ }^{41}$ Similarly, in its presentation during the Senate public hearing, an

\footnotetext{
30 Abikan, A.Ibrahim, "The application of Islamic Law in Civil Causes in Nigerian Courts" Journal of International and Comparative Law, Vol. 6, (June, 2002), 88-115

31 Niki Tobi, op cit, 1 \& Abikan, A.Ibrahim, Op cit, 88-115

32 Joseph Onuche, Same Sex Marriage in Nigeria: A Philosophical Analysis, International Journal of Humanities and Social Science Vol. 3 No. 12 [Special Issue - June 2013], 93-98

33 The people of Lut were commonly known for the commission of sodomy during their own time

34 Qur'an 7: 84: “And We rained down on them a rain (of stones). Then see what was the end of Mujrimin [criminals, polytheists and sinners]." Similarly, the Almighty Allah says: "And We sent Lot who said to his people: "Do you commit lewdness such as no people in creation (ever) committed before you? For you practice your lusts on men in preference to women; you are indeed a people transgressing beyond bounds." Qur'an 11: 80-81

35 Cited in Mulla Mujahiali Sherif, Alliwat (Sodomy), 26 $6^{\text {th }}$ Thursday, 2010, at 1, available at http://almujtaba.com/en/index.php/home?start=240, or http://almahdi.org.uk, accessed on 24/06/2014

36 Qur'an 11:82

37 Qur'an 11:83

38 Cited in Mulla Mujahiali Sherif, Alliwat (Sodomy), 26 ${ }^{\text {th }}$ Thursday, 2010, at 1, available at http://almujtaba.com/en/index.php/home?start=240, or http://almahdi.org.uk, accessed on 24/06/2014

39 Cited in Joseph Onuche, Same Sex Marriage in Nigeria: A Philosophical Analysis, International Journal of Humanities and Social Science Vol. 3 No. 12 [Special Issue - June 2013], 93-98

${ }^{40}$ Quoted in Joseph Onuche, Same Sex Marriage in Nigeria: A Philosophical Analysis, International Journal of Humanities and Social Science Vol. 3 No. 12 [Special Issue - June 2013], 93-98

41 Joseph Onuche, 93-98
} 
organization called "the Queer Alliance of Nigeria"42 has also made known to the committee that sexuality of whatever type is part of the human nature. The homosexuality is inherent in a particular percentage of citizenry in the country and therefore it is not a matter of choice, as no one will be willing to choose to be amongst the marginalized group in the society. ${ }^{43}$ The above organization has made a reference to the Nigeria's constitution which the organization believed to have guaranteed every citizen their fundamental human rights. In a similar case, in a joint Memorandum submitted to the Senate on the Bill by some NGOs such as the Amnesty International, Human Rights Watch (HRW) and the International Gay and Lesbian Human Rights Commission (IGLHRC), they strongly urge the Nigerian Senate not to pass the Same-Sex Marriage (Prohibition) Bill 2011 into law, as it violates the Nigerian Constitution. ${ }^{44}$ However, such outcries and condemnations by the international organizations were disregarded by the Nigerian authority. Thus, the Government in a statement, made its position clear to the international community during the Council meeting of the UN Human Rights which endorsed the adoption of rights of gay, lesbian and transgender people not to be discriminated. The resolution was resulted into serious condemnations by some UN member-countries that are not in support of it. Hence it was against this backdrop, the Nigerian Government through its representative, issued a statement that the UN could be turned into a "guinea pig" of policies that cannot be implemented by member states. He affirmed that same-sex marriage is a criminal offence punishable with imprisonment up to 14 years in the country and that the country is determined to uplift the people's morals. ${ }^{45}$ However, the position of Nigeria did not go down well with some international community, for it has threatened to limit the rights of sexual minorities. ${ }^{46}$

Furthermore, apart from the political institution, the religious leaders in Nigeria are not also left behind in kicking against the notion of same-sex marriage in the country, where they reiterates their support to the Government in preventing the menace. According to Malam Abdulkadir Apaokagi, ${ }^{47}$ in his Friday summons, compared the act of homosexuality with murder. Thus, he said, gays and lesbians deserve a grievous capital punishment such as death penalty. ${ }^{48}$ The Islamic scholar further affirms in his lecture entitled: "The position of Islam on gay marriage" ${ }^{49}$ that gay people were mentally unstable and could bring severe instability to the society in which they lived. ${ }^{50}$ Quoting from the Quran, the scholar hailed the Senate for passing the law, saying that Allah decreed marriages only between members of the opposite sex. He further maintains that: "Any society that tolerates gay marriage would come to destruction the way God destroyed Sodom and Gomorrah for sodomy. They are criminals, Allah Himself describes them so, and it is great that the Senate has criminalized what they are trying to do." He also urged the lower House (i.e. the House of Representatives) to take a cue from the Senate, and do same. ${ }^{51}$ Another Islamic scholar, Shiekh Khalid Aliyu Abubakar, (the Secretary-General) of the National Islamic umbrella organization in Nigeria known as "the Jama'atul Nasrul Islam", also commended the Government in taken a bold courage in making the SSMP Bill 2011 into law. According to him, the Act is not controversial as far as Nigerian Nation and its legal system are concerned. He confirmed that there is no conflict between Islamic law and its conventional counterpart on the prohibition matter. ${ }^{52}$

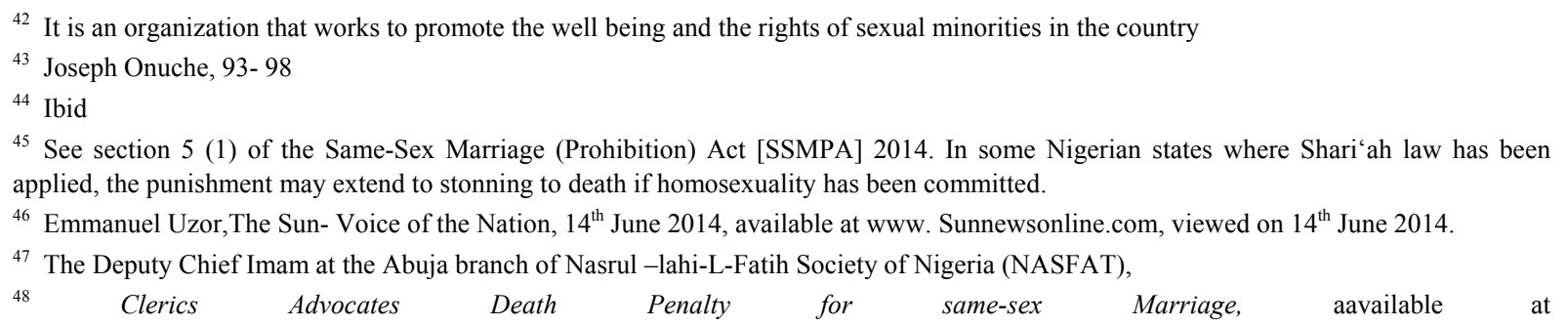

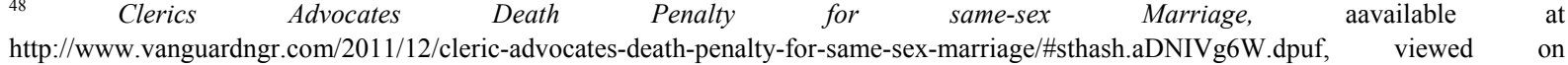
$17 / 06 / 2014$

${ }^{49}$ The scholar's Lecture (Sermon) came against the background of a recent law passed by the Senate banning same-sex marriage and public display of affection by gays in Nigeria. The bill, "Same Sex Marriage (Prohibition) bill 2011" also prescribed 14 years jail sentence for convicted gays in Nigeria. See Clerics Advocates Death Penalty for same-sex Marriage, available at http://www.vanguardngr.com/2011/12/cleric-advocates-death-penalty-for-same-sex-marriage/\#sthash.aDNIVg6W.dpuf, viewed on $17 / 06 / 2014$

${ }^{50}$ Ibid

51 Clerics Advocates Death Penalty for same-sex Marriage, available at http://www.vanguardngr.com/2011/12/cleric-advocates-death-penalty-for-same-sex-marriage/\#sthash.aDNIVg6W.dpuf, viewed on $17 / 06 / 2014$

52 Heather Murdock, Nigerians applaud Anti-Gay Laws, Islamic Court Hand out 20 Lashes, available at http://www.csmonitor.com/World/Africa/2014/0117/Nigerians-applaud-anti-gay-law-as-Islamic-court-hands-out-20-lashes, viewed on $17 / 06 / 2014$ 
In a similar comment, some Christian's clerics have equally followed the suit. While Speaking during a presidential address to mark the $29^{\text {th }}$ Synod of the Diocese at St. Monica's Anglican Church, Woliwo, Onitsha, the Bishop of the Niger, Rt Rev Owen Nwokolo said the church has risen against any thing that is contrary to the Christian faith especially same-sex marriage. He therefore submitted his total support to the Government in waging war against such dubious act, as it is repugnant to all religious teachings and cultural practices in the country. ${ }^{53}$ Thus, a provision in the Bible has equally described such act of same-sex marriage as wickedness and sin. To this end, the Bible says: "But the men of Sodom were wicked and sinners before the Lord exceedingly." 54 He confirmed.

\section{The Protection of Human Rights in the 1999 Nigerian Constitution}

The notion of human rights generally, is an old phenomenon. Particularly in Nigeria, it was known and put into practice since before the advent of the colonial administration. Human rights and fundamental freedoms were recognised in the traditional Nigerian societies. Both Islamic law and most of the Nigerian customs recognizes it. Therefore the idea of human rights was not attributable only to the UN and Regional Charters, but they are also inherent in the peoples' religions, customs and values. These include right to family, kin and clan membership, freedom of thought, speech, belief and association. Others are right to enjoy private property and right to participate in governance of the people affairs. However, when the colonial administrators came, some of such values were eroded and denied, especially those values that have to do with Nigerian's social, political and economic rights. It was until 1922 through the Clifford Constitution that citizens of Nigeria started to regain back some of their values such as having the limited franchise right for the first time after colonization. ${ }^{55}$ Hence from then, the Nigerian electoral process has gradually continued to develop until when all the citizens have regained full right to vote and to be voted for. ${ }^{56}$

The concept of human rights in the 1999 Constitution of the Federal Republic of Nigeria has been rooted from the formation of the United Nations Organisation (UNO) and the subsequent promulgation and adoption of the Universal Declaration of Human Rights (UDHR) in $1948 .^{57}$ In the history of the Nigerian constitutions since independence period to date, provisions were made for Human rights protection. In addition, in the recent (1999) Nigerian constitution, demarcation has been drawn between the human rights that are justiceable and the ones that are not justiceable. To begin with, the term 'justiceability' can simply be defined as an ability to seek for redress from the court of competent jurisdiction in case of any violation. ${ }^{58}$ This of course, may comprises all issues that are related to access to justice. In light of the above, the former (justiceable rights) are rights that can be enforced by the court of law in case of any breach. Whereas, the latter (non-justiceable rights) are rights that cannot not be enforced by the court, and as such, they have been enshrined in the Constitution just for the sake of policy making. This has been considered as set back for the objectives intended to be achieved by the United Nations (UN) in setting out the human rights provisions, which in its resolution propagated for all the human rights without any categorization and distinction. Nigeria is one of the members of UN and signatories to UDHR and other relevant conventions; it has ratified and domesticated the human rights provisions in its constitution in line with the Nigerian legal order enshrined under the 1999 Constitution. The section provides: "No treaty between the Federation and any other country shall have force of law except to the extent to which any such treaty has been enacted into law by the National Assembly." ${ }^{19}$ This provision implies that, although Nigeria is happened to be one of the signatories to UDHR, but could not directly go ahead to enforce the UN Declaration unless provisions of such treaties or conventions have been re-enacted, by municipal legislative authority, into domestic law. To this end, the Supreme Court in the celebrated case of General Sani Abacha vs Gani Fawahinmi ${ }^{60}$ interpreted the above provision of the Constitution (section 12) to imply among other things: "An international treaty to which Nigeria is a signatory does not ipso facto become a law enforceable as such in Nigeria. Such a treaty would have the force of law and therefore justiceable only if the same has been enacted

\footnotetext{
${ }^{53}$ Emmanuel Uzor,The Sun- Voice of the Nation, 14 ${ }^{\text {th }}$ June 2014, available at www. Sunnewsonline.com, viewed on $14^{\text {th }}$ June 2014.

${ }^{54}$ Genesis 13:13

${ }^{55}$ Federal Republic of Nigeria, National Action Plan for the Promotion and Protection of Human Rights in Nigeria, 2006, at 3

${ }^{56}$ Duru, Onyekachi Wisdom Ceazar, The Justiability of the Fundamental Objectives and Directive Principles of State Policy under Nigerian Law, available at http://ssrn.com/abstract=21403613-12, viewed on 19/06/2014

57 Jacob Abiodun Dadaat, "Human Rights under the Nigerian Constitution: Issues and Problems" International Journal of Humanities and Social Science Vol. 2 No. 12 [Special Issue - June 2012] at 33

${ }^{58}$ Duru, Onyekachi Wisdom Ceazar, Op cit

59 section 12 of the 1999 Nigerian Constitution

${ }^{60}$ Sani Abacha vs Gani Fawahinmi (2000) FWLR (pt. 4) 533 at 585-586.
} 
into law by the National Assembly....

In light of the above, all the international instruments and treaties have to be domesticated before they attract the full force of law. For instance the UDHR resolutions have been domesticated in the state constitution but with some modifications. That is to say, the rights domesticated in the Nigerian constitution 1999, are not placed on the equal footings. While some of the rights have been considered with high value and esteem within the realm of the law, other rights are just considered as mere rights, hence cannot be enforceable by the courts. To this end, In Kuti and Others v. AG Federation, ${ }^{62}$ the learned Justice of the Supreme Court Oputa (as he then was) had this to say:

"Not every civil or legal right is fundamental right. The ideal and concept of fundamental rights both derive from the premise of the inalienable rights of man - life, liberty, and the pursuit of happiness. Emergent nations with written constitutions have enshrined in such constitution some of these basic human rights, each right that is thus considered fundamental is clearly spelt out." $" 63$

The African Charter on Human and Peoples Rights which is the replica of what is contained in the UDHR, and has been enforceable in Nigeria by virtue of the Ratification and Enforcement Act. It was stated in Abacha \& Others $v$ Fawehinmi (supra), that the African Charter on Human and Peoples' Rights having been enacted into law in Nigeria by virtue of the Ratification and Enforcement Act was binding on the Nigerian courts and the rights and obligations enacted by it held enforceable. In fact, the Federal High Court, per Nwodo, J. (as he then was) held that Chapter II rights such as the right to health of prison inmates can be enforced by the court through the provisions of the African Charter which entrenches social and economic rights of individuals. These decisions notwithstanding, it is saddening to note that The Charter, and indeed the municipal enactment, is subjugated to the supremacy provisions in section 1(3) of the Constitution, which makes any law inconsistent with the provisions of the Constitution void to the extent of that inconsistency. The implication is that as far as these rights are consigned to Chapter II by the Constitution, sections of the Charter guaranteeing them would appear to be unconstitutional. ${ }^{64}$

The enforceable rights in the Nigerian constitution have been classified and termed as "Fundamental Rights", which have been enshrined under Chapter four of the Constitution. ${ }^{65}$ Other rights are just mere aspirations and have been classified under the Chapter two of the Constitution, which entitled as: "the Fundamental Objectives and Directive Principles of State Policy". It is however the government responsibility towards the effectuation and realization of such rights enshrined under Chapter two of the Constitution. The responsibility of the Government is fully captured by a provision of the Nigerian Constitution 1999 as follows:

"It shall be the duty and responsibility of all organs of government, and of all authorities and persons exercising legislative, executive or judicial powers, to conform to, observe and apply the provisions of this Chapter of this Constitution (i.e. the Fundamental Objectives and Directive Principles of State Policy). ${ }^{.66}$

The observance of the provisions under Chapter two is not the sole duty of the government, but also the private individuals. To this end, the Supreme Court in Attorney-General of Ondo State vs. Attorney-General of the Federation \& 35 ors $^{67}$ held that section 13 quoted above does not only impose a solemn duty to observe the fundamental principles enshrined under Chapter two on the organs of government, but also on private individuals. ${ }^{68}$ The Nigerian Constitution mandates the three organs of government namely the legislature, executive and judiciary to observe, conform and apply the Fundamental Objectives and Directive Principles of State Policy. In Arch. Bishop Olubunmi Okogie v. The Attorney General of Lagos State ${ }^{69}$ it was held that: the Fundamental Objectives in the Constitution are considered as mere policies set out in order to realize the national

${ }^{61}$ Ibid, see also Jacob Abiodun Dadaat, at 38

${ }^{62}$ Kuti and Others v. AG Federation [1985] 8 NWLR (pt 6) 211

${ }^{63}$ Ibid

${ }^{64}$ Duru, Onyekachi Wisdom Ceazar, Op cit

${ }^{65}$ Chiroma Moses Gamzhi, Challenges of Enforcement of Fundamental Human Rights under the Constitution of the Federal Republic of Nigeria, 1999 being an Essay in Partial Fulfillment of the award of Postgraduate Diploma in Law, in the Nigerian Institute of Advance Legal Studies, NIALS, Lagos Campus, Nigeria at 11

${ }^{66}$ Section 13 of the Nigerian Constitution 1999 (as amended)

${ }^{67}$ Attorney-General of Ondo State vs. Attorney-General of the Federation \& 35 ors. (2002) 9NWLR (pt. 772), or (2002) 6 SC (pt. 1) 1

${ }^{68}$ Ibid

${ }^{69}$ (1981) 2 NCLR 337 
ideas. While section 13 of the Constitution makes it a duty and responsibility of the Judiciary among other organs of government to conform to and apply the provisions of Chapter II, Section 6 (6) (c) of the same constitution on the other hand makes it clear that no court has Jurisdiction to pronounce any decision as to whether any organ of government has acted or is acting in conformity with the Fundamental Objectives and Directive Principles of State Policy. It is clear therefore that Section 13 has not made Chapter II of the Constitution Justiceable. ${ }^{70}$

To emphasise further, the rights classified under Chapter four of the Nigerian Constitution 1999 (as amended), are mostly those rights termed as civil and political rights or the first generation human rights as they are popularly known within the international arena. Such rights includes: right to life, ${ }^{71}$ right to dignity of human person; ${ }^{72}$ right to personal liberty ${ }^{73}$ right to fair hearing $;{ }^{74}$ right to private and family life ${ }^{75}$ right to freedom of thought, conscience and religion; ${ }^{76}$ right to freedom of expression; ${ }^{77}$ right to peaceful assembly and association; ${ }^{78}$ right to freedom of movement; ${ }^{79}$ right to freedom from discrimination, $;{ }^{80}$ and right to acquire and own movable property any where in Nigeria. ${ }^{81}$ Meanwhile, the rights enshrined under Chapter two of the Constitution are considered under international law as social, economic and cultural rights, which are some times been addressed as "the second generation of human rights." Most of such rights as contained under Chapter two of the 1999 Constitution include: observance of the principles of democracy and social justice; ${ }^{82}$ political objectives ${ }^{83}$ economic rights; ${ }^{84}$ social rights $;{ }^{85}$ educational rights; $;{ }^{86}$ foreign policy objectives; ${ }^{87}$ environmental objectives, ${ }^{88}$ and directive on Nigerian culture. ${ }^{89}$

\section{The Anti-Gay Law and the Human Rights Provisions under the 1999 Nigerian Constitution}

In January 2006, the Nigerian Minister for Justice presented to the Nigerian Federal Council a Bill that would punish any person engaging in same-sex marriages and matters related thereto. Such a bill according to some opinions launches a vigorous attack on freedom of peaceful assembly and association, as well as right to freedom from discrimination in Nigeria. ${ }^{90}$ The Same-Sex Marriage (Prohibition) Bill 2011 was signed into law in January 2014. The Act contains some provisions which among other things prescribed the punitive measures against anyone who violates the provisions of the Act. Specifically, the Act prescribed up to 14 years imprisonment against any person who enters into a same-sex marriage contract and against any same-sex couples that cohabit. Similarly, the Act criminalises the formation, operation and support of 'gay clubs, societies and organisations, hence by prescribing a punishment which attracts up to 10 years imprisonment against such violators. However, the Act is alleged to have been in contravention of the Nigerian Constitution 1999, particularly the Chapter Four of the Constitution which deals with the right to privacy; right to freedom of expression; and right to freedom of peaceful association. ${ }^{91}$

\footnotetext{
${ }^{70}$ Duru, Onyekachi Wisdom Ceazar, Op cit

${ }^{71}$ Section 33 of the Nigerian Constitution 1999 (as amended)

${ }^{72}$ Section 34 of the Nigerian Constitution 1999 (as amended)

${ }^{73}$ Section 35 of the Nigerian Constitution 1999 (as amended)

${ }^{74}$ Section 36 of the Nigerian Constitution 1999 (as amended)

${ }^{75}$ Section 37 of the Nigerian Constitution 1999 (as amended)

${ }^{76}$ Section 38 of the Nigerian Constitution 1999 (as amended)

${ }^{77}$ Section 39 of the Nigerian Constitution 1999 (as amended)

${ }^{78}$ Section 40 of the Nigerian Constitution 1999 (as amended)

${ }^{79}$ Section 41 of the Nigerian Constitution 1999 (as amended)

${ }^{80}$ Section 42 of the Nigerian Constitution 1999 (as amended)

${ }^{81}$ Section 43 of the Nigerian Constitution 1999 (as amended)

${ }^{82}$ Section 14 of the Nigerian Constitution 1999 (as amended)

${ }^{83}$ Section 15 of the Nigerian Constitution 1999 (as amended)

${ }^{84}$ Section 16 of the Nigerian Constitution 1999 (as amended)

${ }^{85}$ Section 17 of the Nigerian Constitution 1999 (as amended)

${ }^{86}$ Section 18 of the Nigerian Constitution 1999 (as amended)

${ }^{87}$ Section 19 of the Nigerian Constitution 1999 (as amended)

${ }^{88}$ Section 20 of the Nigerian Constitution 1999 (as amended)

${ }^{89}$ Section 21 of the Nigerian Constitution 1999 (as amended)

${ }^{90}$ A Publication of the International Gays and Lesbians Human Right Commission (IGHLRC), Voices from Nigeria: Gays, Lesbians, Bisexuals and Transgenders Speaks out, November 2006, at 1

${ }^{91}$ See Duru, Onyekachi Wisdom Ceazar, Op cit
} 
Thus, the proponents of same-sex marriage have alleged that the enactment of anti-gay law is in total violation of the fundamental human rights of the minority (Lesbians, Gays, Bisexuals and Transgender LGBT) as enshrined in the 1999 Nigerian Constitution. Particularly, the right to freedom of peaceful assembly and association; ${ }^{92}$ right to freedom of conscience, thought and religion; ${ }^{93}$ right to freedom from discrimination; $;{ }^{94}$ and the right to freedom of private and family life. ${ }^{95}$ They have canvassed arguments to the effect that their right to assemble and associate as gays and lesbians is constitutional and therefore should not be tempered with. According to them, living as gays and lesbians has been convicted out of their conscience and thought, as it is their private family lives to marry one another. However, as it is a principle under the rule of law that, people's human rights shall be protected, it is also the responsibility of a state to make laws for the peace, order and good government of its citizens. ${ }^{96}$ This may include the enactment of any law that has to do with moral and social control of people. To this end, penal laws are been enacted in order to prevent crimes and as well, control moral decadence of the public. The laws enacted in the country, which limits the freedom of people as contained in the constitution should not just be nullified based on the ground of inconsistency with the constitution..$^{97}$ More so, the enactments are also product of the constitution, and they are promulgated by virtue of the constitutional powers conferred on the legislature. ${ }^{98}$ Most of the human rights provisions in the Constitution have set out some proviso in order to limit their application and enforcement. This is because of the common saying: "where your right ends, the right of another person begins." That means, human rights can never be absolute, one cannot hide under it and violates other peoples' rights. More so, it has been provided for in the same Constitution, that sections under Chapter four of the Constitution (i.e. sections 37, 38, 40 , and 42 mentioned above), shall not invalidate any law that is reasonably justifiable in a democratic society. ${ }^{99}$ To this end, the Constitution provides:

"Nothing in Sections 37, 38, 39, 40 and 41 of this Constitution shall invalidate any law that is reasonably justifiable in a democratic society- (a) in the interest of defence, public safety, public order, public morality or public health; or (b) for the purpose of protecting the rights and freedom of other persons." 100

In order to understand the comprehensive meaning and intent of the Human rights provisions in the Constitution, which are claimed to have been violated by the Government, there should be a need also to read such provisions alongside with the provision of section 45 quoted above. It is a cardinal principle of interpretation of statutes that general provisions must not be read in isolation, but must be read alongside with the proviso. ${ }^{101}$

Even prior to the enactment of the anti-gay law in Nigeria, there are provisions in the Nigerian penal laws set out to punish the act of homosexuality in the country. Hence the anti-gay law seems to be old phenomenon within the Nigerian legal system. The only major distinction between the hitherto laws and the current one is that the latter is compiled in a distinct code called "Same-Sex Marriage (Prohibition) Act", whereas, the former laws have been scattered in different penal and native laws of the country. To this end, in the Nigerian Criminal Code Act 1990, which is applicable in the Southern part of Nigeria, homosexuality has been declared as illegal. The section provides that any person that has canal knowledge of an animal or commits homosexuality with a man or has canal knowledge of a woman against the order of nature shall be guilty of an offence (felony) and after conviction, shall be liable to imprisonment for fourteen years. ${ }^{102}$ Similarly, the Act prescribed for the punishment of up to seven years imprisonment for the attempted homosexuality. ${ }^{103}$ Furthermore, it has been prescribed by the Act that any male persons convicted for a gross indecency should be punished for the term which shall extend to three years

\footnotetext{
92 Section 40 of the Nigerian Constitution 1999 (as amended)

93 Section 38 of the Nigerian Constitution 1999 (as amended)

94 Section 42 of the Nigerian Constitution 1999 (as amended)

95 Section 37 of the Nigerian Constitution 1999 (as amended)

${ }^{96}$ Section 4 of the Nigerian Constitution 1999 (as amended)

97 Section 1 (3) of the Nigerian Constitution 1999 (as amended), it provides that: "if any law is inconsistent with the provisions of this constitution, this constitution shall prevail, and that other law shall to the extent of the inconsistency be void."

98 Section 4 of the Nigerian Constitution 1999 (as amended)

99 Section 45 of the Nigerian Constitution 1999 (as amended)

100 Ibid

101 Rafiu Bello, Civilization, Homosexuality and Nigerian Law, Punch Online, Janury 27, 2014, available at http://www.punchng.com/feature/the-law-you/civilisation-homosexuality-and-nigerian-laws/, accessed on 25/06/2014

102 Section 214 (1)-(3) of the Criminal Code Act Chapter 77, 1990 Laws of the Federation of Nigeria, see also section 284 of the Penal Code of Northern Nigeria.

103 Section 215 of the Criminal Code Act Chapter 77, 1990 Laws of the Federation of Nigeria, the section provides: "Any person who attempts to commit any of the offences defined in the last preceding section is guilty of a felony and liable to imprisonment for 7 years."
} 
imprisonment. ${ }^{104}$ It is important to note that there is no difference in terms of punishment against the offenders who commit homosexuality consensually and those who commit it by force or assault. Thus, the Criminal Code provides that an assault with intent to have carnal knowledge with a man (or woman) against the order of nature carries a maximum penalty of 14 years imprisonment as it was prescribed against those who commit the offence consensually. ${ }^{105}$

From the year 2000 henceforth, 12 out of 36 Northern states have adopted Shari'ah as part of their state criminal laws and therefore punish male homosexuals with death by stoning, and female lesbians with up to 50 lashes. The Same-Sex Marriage (Prohibition) Act [SSMPA] $2014^{106}$ includes the following punishments: up to 14 years imprisonment for anyone who enters into a same-sex marriage contract or civil union. ${ }^{107}$ For the purposes of the Act, a 'civil union' covers co-habiting relationships between partners of the same sex. ${ }^{108}$ The Act also punishes anyone who witnesses or supports or abets or aids a same-sex wedding up to 10 years imprisonment. ${ }^{109}$ Similarly, up to 10 years imprisonment against anyone who "registers, operates or participates in gay clubs, societies and organisations"; 110 up to 10 years imprisonment for "direct or indirect" public displays of affection for same-sex couples. ${ }^{111}$

By consideration of the above explanation, it is conclusive to say, that the type of marriage recognized by the Nigerian laws should be the one to be entered into by persons of different sex, and in accordance with the Marriage Act, Islamic Law or Customary Law. ${ }^{112}$ Thus, the SSMPA equally provides that only marriages contracted between a man and a woman shall be recognized as valid one in Nigeria; Any marriage contract or civil union entered into by persons of the same sex is prohibited; ${ }^{113}$ A marriage contract or civil union entered into between persons of the same sex is invalid and illegal and shall not be recognized or entitled to benefits of a valid marriage; ${ }^{114}$ Marriage contracts or civil unions entered into between persons of the same sex by virtue of a certificate issued by a foreign country is void in Nigeria, and any benefits accruing there from by virtue of the certificate shall not be enforced by any court of law in Nigeria; ${ }^{115}$ Marriage or civil union entered into between persons of the same sex shall not be solemnized in any place of worship or any other place whatsoever called in Nigeria; ${ }^{116}$ No such certificate shall be valid in Nigeria. ${ }^{117}$ The SSMPA further criminalizes a number of activities associated with homosexuality including free association through 'gay' organizations. This includes prohibitions on registering gay clubs, societies and organizations, and their activities, processions and meetings; ${ }^{118}$ public showing of same sex amorous relationships directly or indirectly. ${ }^{119}$

Apart from the enactment of the anti-gay law, the implementation and enforcement of the law in Nigeria has not been taken lightly. The Nigerian Governments through their relevant agencies and institutions have been intensifying efforts to prevent what they called a menace (same-sex marriage), thereby ensuring the smooth implementation and enforcement of the law. To this end, it was reported that in Bauchi state, Northern part of

\footnotetext{
${ }^{104}$ Section 217 of the Criminal Code Act Chapter 77, 1990 Laws of the Federation of Nigeria, the section provides: "Any male person who, whether in public or private, commits any act of gross indecency with another male person, or procures another male person to commit any act of gross indecency with him, or attempts to procure the commission of any such act by any male person with himself or with another male person, whether in public or private, is guilty of a felony, and is liable to imprisonment for three years."

${ }^{105}$ Section 352 of the Criminal Code Act

106 The Act was assented by the Nigerian President on $7^{\text {th }}$ January, 2014

107 Section 5 (1) of the SSMPA 2014

${ }^{108}$ See section 7 of the SSMPA 2014. The Act provides: "civil union is defined as 'any arrangement between persons of the same sex to live together as sex partners, and shall include such descriptions as adult independent relationships, caring partnerships, civil partnerships, civil solidarity pacts, domestic partnerships, reciprocal beneficiary relationships, registered partnerships, significant relationships, stable unions, etc"

109 Section 5 (3) of the SSMPA 2014

${ }^{110}$ Section 5 (2) of the SSMPA 2014

111 Section 5 (2) of the SSMPA 2014

${ }_{112}$ Section 7 of the SSMPA 2014

${ }^{113}$ Section 1 (1) of the SSMPA 2014

${ }^{114}$ Section 1 (2) of the SSMPA 2014

${ }^{115}$ Section 1 (3) of the SSMPA 2014

116 Section 2 (1) of the SSMPA 2014

117 Section 2 (2) of the SSMPA 2014

${ }_{118}$ Section 4 (1) of the SSMPA 2014

119 Section 4 (2) of the SSMPA 2014, see also Kaleidoscope Trust Briefing, January 2014 Charity No: 1146274, Nigeria: Same Sex Marriage (Prohibition) Act (SSMPA). 2014
} 
Nigeria, a young man called Mubarak Ibrahim was arraigned before the Shari' ${ }^{\text {ah }}$ Court for the allegation of being a member in a gay club, and was subsequently convicted and sentenced with 20 strokes of cane in accordance with the principles of Islamic injunctions. However, the Presiding judge Nuhu Idris said that, "The sentence could have been more severe but [there was] a lack of witnesses," in his verdict, he added that the accused was sorry for his crime and said he had joined the club after being tricked into it by schoolmates. ${ }^{120}$ In addition, many charges have been lying before the courts in Bauchi state including the case of a Christian who was arraigned before a civil court and could face up to 14 years imprisonment if convicted. ${ }^{121}$

\section{Conclusion}

The concept of same-sex marriage is a growing trend which apart from its legal implication also has a negative impact on the Nigerian religions, customs, norms and values. It was unpopular to Nigerian people, until recent time when it becomes a recurrent issue. In contrast, the concept of human rights has for long been recognized by the Nigerian religions, norms and traditions. The protection of human rights is provided for under Islamic law, which applies in the Northern part of Nigeria. Meanwhile, various customs and traditions in the country have also recognized the protection of human rights as a mark of honour and respect to human dignity and person. The religions and customs in Nigeria have recognized marriage only as a union between male and female with a view to becoming husband and wife. Similarly, the Nigerian legislation has also built upon this notion, and accordingly prohibits the same-sex marriage as it is contrary to the public policy and morals. The constitution of Nigeria has provided for rights to freedom of private and family life; freedom of conscience, thought and religion; freedom of peaceful assembly and association; and freedom from discrimination. However, such rights cannot be applied or enforced in contravention to other constitutional provisions and primary legislation in the country. In fact, the human rights provisions in the Constitution should not be interpreted in isolation from other provisions that are connected therewith. The Same-Sex Marriage (Prohibition) Act in Nigeria is indeed a child of the Constitution of the Federal Republic of Nigeria, and was enacted by virtue of the powers conferred on the legislature to make laws for the peace, order and good governance in the country. It is obvious that human beings must have their rights protected, but that does not also go to the extent of violating or derogating other provisions in the Constitution or the primary legislation in the country. Therefore, the provisions of the SSMPA do not in any way contravene the Nigeria Constitution. In fact, the enactment process and the Act itself are legal and constitutional.

\section{References}

A Brief overview of Male and Female Reproductive System. (n. d.). Retrieved June 24, 2014, from https://www.boundless.com/microbiology/diseases/microbial-genitourinary-system-diseases/brief-overview -male-and-female-reproductivesystem-1/

A Publication of the International Gays and Lesbians Human Right Commission (IGHLRC). (2006, November). Voices from Nigeria: Gays, Lesbians, Bisexuals and Transgenders Speaks out.

Abikan, A. I. (2002, June). The application of Islamic Law in Civil Causes in Nigerian Courts. Journal of International and Comparative Law, 6.

Bello, R. (2014, January 27). Civilization, Homosexuality and Nigerian Law. Punch Online. Retrieved June 25, 2014, from http://www.punchng.com/feature/the-law-you/civilisation-homosexuality-and-nigerian-laws/

Clerics Advocates Death Penalty for same-sex Marriage. (n. d.). Retrieved June 17, 2014, from http://www.vanguardngr.com/2011/12/cleric-advocates-death-penalty-for-same-sex-marriage/\#sthash.aDNI Vg6W.dpuf

Dadaat, J. A. (2012, June). Human Rights under the Nigerian Constitution: Issues and Problems. International Journal of Humanities and Social Science, 2(12).

Duru, O. W. C. (n. d.). The Justiability of the Fundamental Objectives and Directive Principles of State Policy under Nigerian Law. Retrieved June 19, 2014, from http://ssrn.com/abstract=21403613-12

Emmanuel Uzor,The Sun-Voice of the Nation, $14^{\text {th }}$ June 2014. (n. d.). Retrieved June 14, 2014, from http://www.Sunnewsonline.com

Federal Republic of Nigeria, National Action Plan for the Promotion and Protection of Human Rights in Nigeria,

120 Heather Murdock, Nigerians applaud Anti-Gay Laws, Islamic Court Hand out 20 Lashes, available at http://www.csmonitor.com/World/Africa/2014/0117/Nigerians-applaud-anti-gay-law-as-Islamic-court-hands-out-20-lashes, viewed on $17 / 06 / 2014$

121 Ibid 
2006.

Gamzhi, C. M. (n. d.). Challenges of Enforcement of Fundamental Human Rights under the Constitution of the Federal Republic of Nigeria, 1999 being an Essay in Partial Fulfillment of the award of Postgraduate Diploma in Law, in the Nigerian Institute of Advance Legal Studies, NIALS, Lagos Campus, Nigeria.

Heather Murdock, Nigerians applaud Anti-Gay Laws, Islamic Court Hand out 20 Lashes. (n. d.). Retrieved June 17 , 2014, from http://www.csmonitor.com/World/Africa/2014/0117/Nigerians-applaud-anti-gay-law-as-Islamic-court-hand s-out-20-lashes

Isma'il, M. I. (n. d.). Sahih Al Bukhari. Kitab an Nikah Book 7, Volume 62, Hadith No. 3 \& 4.

Istimblli, M. M., \& Eliwa, A. (n. d.). The Brides' Boon- Tuhfat Al- A'rous, p 14. Retrieved December 27, 2013, from http://www.islambasics.com

Kaleidoscope Trust Briefing, January 2014 Charity No: 1146274, Nigeria: Same Sex Marriage (Prohibition) Act (SSMPA) 2014.

Nigerian Law Reform Commission. (2006). The working paper on the Reform of the laws of marriage in Nigeria (Vol. II) Abuja, Nigeria.

Onuche, J. (2013, June). Same Sex Marriage in Nigeria: A Philosophical Analysis. International Journal of Humanities and Social Science, 3(12).

Oxford Dictionaries Language Matters. (n. d.). Retrieved June 14, 2014, from http://www.oxforddictionaries.com/definition/english/marriage

Pink News. (n. d.). Oxford Dictionary will change the Definition of 'Mariage' to include equal marriage. Retrieved June 14, 2014, from http://www.pinknews.co.uk/2013/07/25/oxford-dictionary-will-change-the-definition-of-marriage-to-includ e-equal-marriage/

Sham, S. I. (n. d.). Some aspects of Marriage and Divorce in Muslim Family Law. Retrieved June 9, 2014, from http://www.pu.edu.pk/szic/journal/cu...20Divorce).pdf

Sherif, M. M. (2010). Alliwat (Sodomy), 26 ${ }^{\text {th }}$ Thursday, 2010, at 1. Retrieved June 24, 2014, from http://almujtaba.com/en/index.php/home?start=240

The Bible, Genesis 13:13

The Constitution of the Federal Republic of Nigeria (1999) as amended.

The Criminal Code Act Chapter 77, 1990 Laws of the Federation of Nigeria.

The Deputy Chief Imam at the Abuja branch of Nasrul -lahi-L-Fatih Society of Nigeria (NASFAT),

The Matrimonial Causes Act,No. 18 of 1970.

The Penal Code of Northern Nigeria.

The Same-Sex Marriage (Prohibition) Act [SSMPA] 2014.

Tobi, N. (1996). Sources of Nigerian Law. MIJ Professional Publishers Limited, Lagos: Nigeria.

\section{Copyrights}

Copyright for this article is retained by the author(s), with first publication rights granted to the journal.

This is an open-access article distributed under the terms and conditions of the Creative Commons Attribution license (http://creativecommons.org/licenses/by/3.0/). 